\title{
BLOOD ESTRADIOL LEVEL IN BULL SIRES INFLUENCES SPERM COUNT AND EFFECTIVENESS OF ARTIFICIAL INSEMINATION
}

\section{A.I. ABILOV', G.V. ESKIN ${ }^{1}$, N.A. KOMBAROVA ${ }^{2}$}

${ }^{1}$ L.K. Ernst All-Russian Research Institute of Animal Husbandry, Federal Agency of Scientific Organizations, pos. Dubrovitsy, Podolsk Region, Moscow Province, 142132 Russia;

${ }^{2}$ Head Center for Reproduction of Farm Animals OAO, 3, ul. Tsentralnaya, pos. Bykovo, Podolsk Region, Moscow Province, 142143 Russia, e-mail komnina@list.ru

Received May 13, 2016

\section{Abstract}

Wide use of artificial insemination necessitates a deeper understanding of how hormones and immune system influence on semen production in sires. With this regard, the role of follicle stimulating hormone and luteinizing hormone in spermatogenesis is under consideration. Blood testosterone and estradiol levels are related and depend on a testosterone-estradiol binding globulin function. We first examined seasonal effects of blood estradiol levels as a reproduction marker in Holstein bull sires and showed the relationship between the blood estradiol concertation, semen fertilizing ability, semen volume, and semen concentration which, in turn, impact on the results of artificial insemination. Estradiol level in Holstein sires aged $30 \pm 6$ months $(n=18)$ was assayed using Immuno-FA-E ELISA kit and a Uniplan equipment (ZAO Pikon, Russia). The effectiveness of artificial insemination was tested in 214 cows. We showed that in the bulls the blood estradiol level varied significantly depending on a season $(\mathrm{P}<0.001)$. In spring, the lowest $(0.100 \mathrm{nmol} / \mathrm{l})$ estradiol level detected in $78 \%$ of the bulls was mostly characteristic, and only in $17 \%$ of the bulls estradiol was beyond $0.200 \mathrm{nmol} / \mathrm{l}(\mathrm{P}<0.001)$. At autumn, blood estradiol concentration increased in $94 \%$ bulls $(\mathrm{P}<0.001)$. When estradiol level rises two times and more, a $31 \%$ decrease in semen volume per ejaculation is observed (i.e. $3.4 \mathrm{ml}$ vs $4.6 \mathrm{ml}$ ) which results in about $50 \%$ decrease in semen dose number (112 vs 171). When low blood estradiol on the day of semen collecting, a 12-17\% success rate occurred in cows after a single insemination $(P<0.05)$, and 17-29\% heifers became pregnant to first insemination $(\mathrm{P}<0.001)$. Thus the blood estradiol in bulls additionally indicates a fertilizing ability of the semen and can be used to improve effectiveness of artificial insemination technique.

Keywords: estradiol, bull sires, seasonal changes, semen indices, success rate of insemination

For effective breeding and artificial insemination of farm animals, the rational use of sires' sperm [1] should be employed, which requires, in turn, an indepth research of the role of the hormonal and immune systems in the sperm production. Even V.K. Milovanov [2] indicated to a major importance of sex hormones for normal functioning of both reproductive organs and the whole body of sires. Sexual function of animals is known to be under neuroendocrine control. Hormones exert their effects on the metabolism and all physiological functions at very low concentrations $\left(10^{-6}-10^{-12} \mathrm{~mol} / \mathrm{l}\right)$ [3]. In all mammalians, spermatogenesis is modulated by peptide and steroid hormones, such as folliclestimulating hormone (FSH) and luteinizing hormone $(\mathrm{LH})$, testosterone, estradiol, etc. [4]. Under the influence of $\mathrm{LH}$, which is secreted by the pituitary gland after puberty, Leydig cells begin actively to synthesize testosterone which acts on Sertoli cells. Steroid hormones secreted by the testes are represented by androgens and progesterone. They can easily penetrate the cytoplasm and control the cell function, with the participation of specific high-molecular-weight protein receptors [3, 5-7].

Significant variations in the testosterone concentrations have been documented in animals of different origin. Thus, in the Sverdlovsk region, testos- 
terone concentrations in sires imported from abroad were 1.64 times higher than those in domestic bulls (14.28 \pm 2.26 vs. $8.72 \pm 1.92 \mathrm{nmol} / \mathrm{l})$ [8]. M. Anderson [9] reported a positive correlation between the testosterone concentrations in bulls and the pregnancy occurrence in cows. In addition, there was a high positive correlation between the sperm counts in the semen and the amounts of testosterone, as well as a negative correlation between the semen $\mathrm{pH}$ and testosterone blood concentrations [10]. Testosterone levels in the blood of bulls correlate with their age and breed (higher in beef breeds vs. milk breeds) as well as exogenous factors [11). A positive correlation has been identified between the concentrations of cholesterol and testosterone in bulls, where the latter increases when the former is raised [12].

Testosterone-estradiol binding globulin, involved in transport, regulatory and protective functions, plays a major role in the formation of the testosterone/estradiol complex. A certain amount of androgens is converted to DHT and estradiol. Estradiol is synthesized from testosterone by the enzyme aromatase $[13,14]$. In mammalian males, the adrenal glands also produce estrogens, moreover, their positive impact on the quality of sperm is observed.

Estrogens influence the development of the genitals and the secondary sexual characteristics, fat metabolism (in particular, increase the plasma concentrations of phospholipids and $\beta$-lipoprotein, reduce the levels of cholesterol and $\alpha$-lipoprotein), stimulate protein anabolism and the growth hormone production, and slow bone growth in mature adult animals. Under influence of estrogens, the reticuloendothelial system is stimulated, the body's resistance to infections increases, and tissue regeneration is enhanced [3]. LH induces the secretion of androgens in the testes, stimulates the development of interstitial tissue and the production of the male hormone testosterone, and, together with $\mathrm{FSH}$, promotes the proliferation of the seminiferous tubules (the initial stages of spermatogenesis). In males and females, FSH promotes the development of sperm and egg cells, respectively $[2,3]$.

However, at high doses, estrogens can cause the opposite effect (up to necrotic phenomena in the kidneys and liver) [3]. With increases in the concentrations of estradiol over the upper limits, worsening of spermatologic parameters has been revealed [15]. The excess weight in sires may serve as an indirect signal of excessive amounts of estrogens and worsened quantitative and qualitative indicators of the sperm [16, 17].

A.I. Abilov et al. [11] revealed the dependence of the blood concentrations of estradiols in sires on exogenous factors. Furthermore, the quantitative indicators of the sperm production increased with decreasing amounts of estradiol. There is evidence on the relationship between the spermatozoa autoantibodies in sires and the estradiol concentrations [18].

With increasing productivity in cattle, hormonal processes, metabolic rate [19] and, as a consequence, the reproductive capacity are changed. Therefore, it is important to take into account the productive type of the animal when studying its hormonal status.

In view of the discussion on the role of estrogens in the sperm production, papers assessing the impact of phyto-, xenoestrogens and chemically synthesized estradiol on the metabolism and animal reproductive function are also of interest. Xenoestrogens demonstrate activity similar to that of the endogenous estrogens and mimic their properties, therefore, influencing the synthesis, secretion, transport, metabolism, binding and excretion of endogenous hormones involved in the regulation of homeostasis, reproduction and development [20]. Data are available for the negative impact of phytoestrogens on reproductive function. For instance, it has been shown that phytoestrogens may inhibit LH and 
FSH synthesis in women [21] and sexual behavior in animals [22].

In this paper, we have first defined the blood estradiol concentrations in sires in connection to the quantity and quality of sperm production, depending on the season, and how the sire's estradiol status on the day of semen collection could affect the performance of artificial insemination.

The aim of the study was to evaluate the influence of serum endogenous estradiol on the sperm productivity in sires and the efficacy of the insemination using the collected sperm.

Technique. Eighteen Holstein sires aged $30 \pm 6$ months were selected to enter the study (Head Center for Reproduction of Farm Animals, 2012-2014). The animals received a diet balanced according to the nutritional standards by L.K. Ernst All-Russian Research Institute of Animal Husbandry (VIZh), and were maintained under the conditions met the established requirements and standards [23].

Blood samples were collected from the jugular vein 1 hour after collecting semen. The blood serum was separated and stored at $-18 \ldots-20{ }^{\circ} \mathrm{C}$ until testing. Serum concentrations of estradiol were determined by enzyme immunoassay (ELISA) using the Immuno-FA-E test kit and a Uniplan AFG-01 analyzer (JSC Picon, Russia).

Estrus in cows (the Klenovo-Chegodaevo experimental farm, New Moscow, 2012-2014) was determined twice, the optimal time for insemination was identified visually by the standing reflex, and by rectal examination, based on the follicle maturity. Animals were inseminated two times per estrus with a 10-12 hour interval. Insemination was considered productive in the absence of re-heat, and based on a rectal examination on days 45-60 after the last insemination.

The significance of differences between the compared options was evaluated by Student's $t$-test. The tables below summarize mean values $(X)$ and mean deviations $( \pm x)$.

Results. When evaluating endogenous blood estradiol concentrations in Holstein sires depending on the season, we revealed (Fig.) that in the spring (April 23, 2012) it averaged to $0.084 \pm 0.070 \mathrm{nmol} / \mathrm{l}$, and in the autumn (September 5 and October 18, 2012) it significantly, almost 2.5-fold, increased and amounted up to $0.204 \pm 0.060 \mathrm{nmol} / \mathrm{l}(\mathrm{P}<0.001)$.

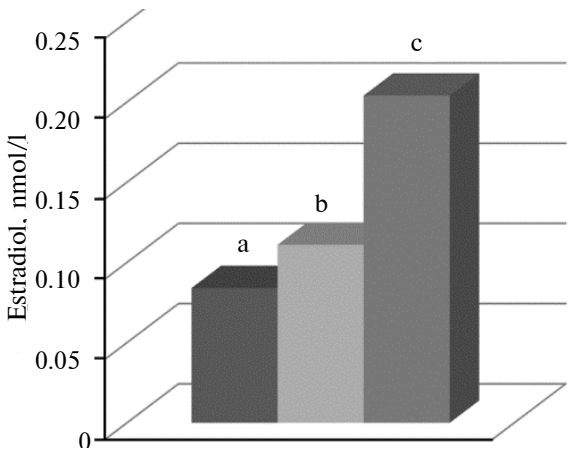

Seasonal blood estradiol concentrations in the Holstein sires: $\mathrm{a}-$ spring, $\mathrm{b}-$ summer, $\mathrm{c}-$ autumn $(n=18$, the animals aged $30 \pm 6$ months; $\mathrm{P}<0.001$; Moscow Province, 2012).

Based on these data, the sires were conventionally assigned to groups by the estradiol levels: low $(0.100 \mathrm{nmol} / \mathrm{l})$ for group I, mean (0.101-0.200 nmol/l) for group II, and high (>0.200 nmol/l) for group III. The distribution of all the animals in groups according to the seasonal estradiol levels is presented in Table 1.

It appeared that most of sires $(77.80 \%$ on average in the sample) had minimum estradiol level in the spring $(0.100 \mathrm{nmol} / \mathrm{l})$, and only in $16.80 \%$ sires on average the concentrations were significantly $(\mathrm{P}<0.001)$ higher than the maximum value $(0.200 \mathrm{nmol} / \mathrm{l})$. In the autumn, a significant increase of the estradiol amount $(\mathrm{P}<0.001)$ was recorded in $94.28 \%$ sires.

The quantitative estimation of the sperm production in sires showed (Table 2) that with a significant $(\mathrm{P}<0.001)$ increase in blood estradiol, as com- 
pared to that in group I, the quantitative indices of sperm decreased and, as a consequence, there was a decrease in an output of qualitative semen doses per ejaculate, in a total number of qualitative doses (approximately by $50 \%$ ), and in the ejaculate semen volume (by $31 \%$ ). We suppose this is due to the fact that when the male experience hyperestrogenization, there is an increase in the level of testosterone-estradiol binding globulin, which inhibits the function of free testosterone and reduces the number of mature spermatozoa.

1. The proportion $(\%)$ of Holstein sires conventionally assigned to groups of different estradiol levels by the seasons $(X \pm x, n=18$, the animals aged $30 \pm 6$ months, Moscow Province, 2012)

\begin{tabular}{l|ccc}
\hline \multicolumn{1}{c|}{$\begin{array}{c}\text { Date of testing (number } \\
\text { of animals examined) }\end{array}$} & \multicolumn{3}{|c}{ Estradiol, nmol/1 } \\
\cline { 2 - 4 } April 23 $(n=18)$ & up to 0.100 (group I) & $0.101-0.200$ (group II) & $>0.200$ (group III) \\
July 24 $(n=18)$ & $77.80 \pm 9.80$ & $5.56 \pm 5.40$ & $16.80 \pm 8.78$ \\
September 5 and October 18 $(n=35)$ & $51.11 \pm 11.49$ & $33.33 \pm 11.10$ & $5.56 \pm 5.40$ \\
N o t e. Differences between groups are significant at P $<0.001$. & $48.57 \pm 8.45$ & $45.71 \pm 8.42$ \\
\hline
\end{tabular}

2. Quantitative characteristics of sperm production in Holstein sires conventionally assigned to groups of different estradiol levels $(X \pm x, n=18$, the animals aged $30 \pm 6$ months, Moscow Province, 2012)

\begin{tabular}{|c|c|c|c|}
\hline \multirow{2}{*}{ Parameter } & \multicolumn{3}{|c|}{ Estradiol, nmol/1 } \\
\hline & up to 0.100 (group I) & $0.101-0.200$ (group II) & $>0.200($ group III $)$ \\
\hline Number of sires, $n$ & 7 & 4 & 7 \\
\hline Estradiol, nmol/1 & $0.06 \pm 0.02$ & $0.16 \pm 0.03^{*}$ & $0.26 \pm 0.04^{*}$ \\
\hline Ejaculate volume, $\mathrm{ml}$ & $4.6 \pm 0.9$ & $3.4 \pm 1.1$ & $3.5 \pm 0.9$ \\
\hline Sperm counts in ejaculate, bln $/ \mathrm{ml}$ & $1.3 \pm 0.3$ & $1.4 \pm 0.3$ & $1.3 \pm 0.2$ \\
\hline Doses frozen per one ejaculate & $170.6 \pm 69.4$ & $146.7 \pm 37.4$ & $112.1 \pm 32.3$ \\
\hline * Differences vs. group I are sigl & at $\mathrm{P}<0.001$ & & \\
\hline
\end{tabular}

In assessing semen fertility, sires were divided into groups depending on the estradiol level on the day of semen collection (autumn 2013), i.e. 0.240$0.320(\mathrm{~min}), 0.321-0.360$ (mean) and $>0.361 \mathrm{nmol} / \mathrm{l}(\max )$. We evaluated the pregnancy occurred from the first insemination (cows that were inseminated for the first time after calving) and from singel insemination (regardless of the multiplicity of coming in heat). As seen from the data (Table. 3), the lower the endogenous blood estradiol levels on the day of the semen collection, the more effective the insemination. At the lowest (within this investigation) concentration of estradiol in sires $(0.240-0.320 \mathrm{nmol} / \mathrm{l})$, the performance of one insemination by their sperm was the highest $(62.03 \pm 3.86 \%)$, while at maximum estrogenization level it was the lowest $(45.45 \%)$. Similar data were obtained for the first insemination. In both cases, differences vs. minimum values were significant at $\mathrm{P}<0.05$.

3. Insemination by sperm from Holstein sires having different estradiol levels on the day of semen collection $(X \pm x$, the sires aged $30 \pm 6$ months, Klenovo-Chegodaevo Experimental Farm, New Moscow, 2013-2014)

\begin{tabular}{|c|c|c|c|c|c|c|c|c|}
\hline \multirow{4}{*}{ Estradiol, nmol/1 } & \multicolumn{8}{|c|}{ Number of cows } \\
\hline & \multicolumn{2}{|c|}{ inseminated } & \multicolumn{6}{|c|}{ pregnant } \\
\hline & \multirow{2}{*}{ total } & \multirow{2}{*}{ first } & \multicolumn{3}{|c|}{ from one insemination } & \multicolumn{3}{|c|}{ from first insemination } \\
\hline & & & total & $\%$ & vs. control, \% & total & $\%$ & vs. control, $\%$ \\
\hline $0.240-0.320$ (control) & 79 & 52 & 49 & $62.03 \pm 3.86$ & & 31 & $59.62 \pm 4.81$ & \\
\hline $0.321-0.360$ & 91 & 59 & 46 & $50.55 \pm 3.71$ & $-11.98^{*}$ & 25 & $42.37 \pm 4.55$ & $-17.25^{*}$ \\
\hline$>0.361$ & 44 & 29 & 20 & $45.45 \pm 5.31$ & $-16.58^{*}$ & 9 & $31.03 \pm 6.07$ & $-28.59^{*}$ \\
\hline Total & 214 & 140 & 115 & $53.74 \pm 2.41$ & -8.29 & 65 & $46.43 \pm 2.98$ & $-13.19^{*}$ \\
\hline * Differences & are sig & ficant & $\mathrm{P}<0$. & & & & & \\
\hline
\end{tabular}

A probable cause of the observed variations in the amount of endogenous estradiol depending on the season might be an unequal hypothalamic response to incoming signals. In some cases, this may result in the deficiency of sex hor- 
mone binding globulin, as well as in increased levels of $\mathrm{LH}$ and $\mathrm{FSH}$, leading to manifestation of the primary and secondary testicular failure that may cause a drastic change in blood estradiol concentrations [19]. Our findings are consistent with the results showing that hyperestrogenization increases the amount of testosterone-estradiol binding globulin, and this in turn suppresses the free testosterone function and leads to deterioration of spermatologic parameters [15], including reduced sexual activity and number of spermatozoa in the ejaculate. Increased serum estradiol concentrations may also serve as an indicator of the onset of fatty liver disease (especially if sires are fed with concentrates).

Thus, the level of endogenous blood serum estradiol in sires significantly $(\mathrm{P}<0.001)$ varies depending on the season, that affects the sperm productivity $(\mathrm{P}<0.001)$ and the insemination $(\mathrm{P}<0.05)$. Low levels of estradiol exert a positive effect on quantitative characteristics of sperm production with an increase in ejaculate volume by $31 \%$, and in the output of high-quality doses by $52 \%$. The number of successful inseminations, resulted in pregnancy from single or from the first insemination, is inversely proportional to the blood estradiol level in sires on the day of semen collection. These data can be used as an additional test in predicting the results of artificial insemination.

\section{REFEREN C ES}

1. Ernst L.K., Subboti n A.D. Materialy Mezhdunarodnoi nauchno-prakticheskoi konferentsii "Rol' $i$ znachenie metoda iskusstvennogo osemeneniya sel'skokhozyaistvennykh zhivotnykh $v$ progresse zhivotnovodstva $X X-X X I$ vekov» [Proc. Int. Conf. «Artificial insemination and progress in animal husbandry in XX-XXI»]. Dubrovitsy, 2004: 10-26 (in Russ.).

2. $\mathrm{M}$ i lo va n o v V.K. Biologiya vosproizvedeniya $i$ iskusstvennogo osemeneniya zhivotnykh [Biology of animal reproduction and artificial insemination]. Moscow, 1962 (in Russ.).

3. Ali e v A.A. Obmen veshchestv u zhvachnykh zhivotnykh [Metabolism in ruminants]. Moscow, 1997 (in Russ.).

4. Kumanov P., Nandipati K., Tomova A., Agarwal A. Inhibin B is a better marker of spermatogenesis than other hormones in the evaluation of male factor infertility. Fertil. Steril., 2006, 86: 332-338.

5. S ve rd loff R., B k h a s i n Sh. V knige: Endokrinologiya /Pod redaktsiei N. Lavina [In: Endocrinology. N. Lavin (ed.)]. Moscow, 1999: 369-409.

6. B row d e r L. Developmental biology. Philadelphia, Saunders, 1980: 146-231.

7. Biology of fertilization. V. 3. The fertilization response of the egg. C.B. Metz, A. Monroy (eds.). Academic Press, Orlando, FL, 1985: 1-44.

8. Mymrin V.S., Khalturina L.V., Shkuratova I.A., Ryaposova M.V. Molochnoe i myasnoe skotovodstvo, 2012, 4: 7-9 (in Russ.).

9. Anders o n M. Relationship between GnRH-induced sperm motility and fertility in Ayrshire bulls. Animal Reprod. Sci., 1992, 27(2): 107-111.

10. Chacu r M.G.M., Mizusaki K.T., Gabrie 1 Filho L.R.A., Oba E., Ra mos A.A. Seasonal effects on semen and testosterone in Zebu and Taurine bulls. Acta Scientiae Veterinariae, 2013, 41: pub. 1110 .

11. Abilov A.I., Ko mbarova N.A., Mityas hova O.S. Materialy X Konferentsii molodykh uchenykh s mezhdunarodnym uchastiem «Sovremennye dostizheniya i problemy biotekhnologii sel'skokhozyaistvennykh zhivotnykh - BioTekhZH-2015» [Proc. X Int. Young Scientists Conf. «Recent advances and challenges in farm animals' biotechnology - BioTechAnimals-2015]. Dubrovitsy, 2015: 182-192 (in Russ.).

12. Amerkhanov Kh.A., Abilov A.I., Eskin G.V., Kombarova N.A., Turbi na I.S., Fedorova E.V., Varennikov M.V., Gusev I.V. Concentration of testosterone and cholesterol in blood serum of servicing bulls depending on their type of productivity, age and the season. Sel'skokhozyaistvennaya biologiya [Agricultural Biology], 2014, 2: 59-66 (doi: 10.15389/agrobiology.2014.2.59rus) (in Russ.).

13. Reznikov A.G., Varga S.V. Antiandrogeny [Anti-androgens]. Moscow, 1988 (in Russ.).

14. Reznikov A.G. Polovye gormony $i$ differentsiatsiya mozga [Sexual hormones and brain differentiation]. Kiev, 1982 (in Russ.).

15. Gutorova N.V., O s adchuk L.V., Kleshov M.A., Kuznetsova N.N., Osad c hu k A.V. Problemy reproduktsii, 2010, 6: 89-93 (in Russ.).

16. Fejes I., Koloszar S., Zavaczki Z., Daru J., Szollosi J., Pal A. Effect of 
body weight on testosterone, estradiol ratio in oligozoospermie patients. Arch. Androl., 2006, 52: 97-102.

17. Q i n D.D., Yuan W., Z hou W.J., Cu i Y., W u J., G a o E. Do reproductive hormones explain the association between body mass index and semen quality? Asian J. Androl., 2007, 9: 827-834.

18. Abilov A.I., A merkhanov Kh.A., Eskin G.V., Fedorova E.V., Zha voronkova N.V., Ko mbarova N.A., Varen ni kov M.V. Zootekhniya, 2013, 11: 9-11 (in Russ.).

19. S mirnova E.V., Nezhdanov A.G., Retsky M.I., Bratchenko E.V., Pa p in N.E., Stepanov A.V., Shushlebin V.I., Chus ova G.G. The metabolic profile of late pregnant cows of various ethological activity types. Sel'skokhozyaistvennaya biologiya [Agricultural Biology], 2014, 2: 67-71 (doi: 10.15389/agrobiology.2014.2.67rus) (in Russ.).

20. Diamanti-Kandarakis E., B ourguignon J.P., Giudice L.C., Hauser R., Prin s G.S., S o t o A.M., Z o e 11 e r R.T., G o r e A.C. Endocrine-disrupting chemicals: an Endocrine Society scientific statement. Endocr. Rev., 2009, 30(4): 293-342 (doi: 10.1210/er.2009-0002).

21. Hooper L., Ryder J.J., Kurzer M.S., Lampe J.W., Messina M.J., Phipps W.R., $\mathrm{C}$ as sidy A. Effects of soy protein and isoflavones on circulating hormone concentrations in pre- and post-menopausal women: a systematic revive and meta-analysis. Hum. Reprod. Update, 2009, 15: 423-440.

22. Patisaul H.B., Jefferson W. The pros and cons of phytoestrogens. Front. Neuroendocrin., 2010, 31(4): 400-419.

23. Natsional'naya tekhnologiya zamorazhivaniya $i$ ispol'zovaniya spermy plemennykh bykovproizvoditelei /Pod redaktsiei N.M. Reshetnikovoi, A.I. Abilova [National Technique for freezing and usage of sperm from bull sires. N.M. Reshetnikova, A.I. Abilov (eds.)]. Moscow, 2008 (in Russ.). 